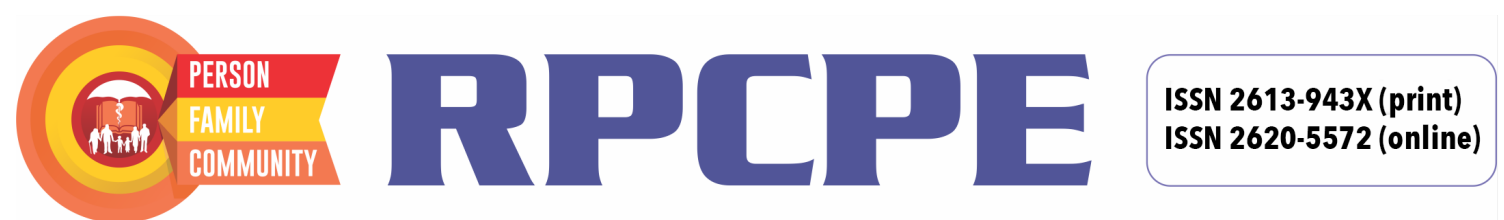

Journal Homepage:

Review of Primary Care Practice and Education

https://jurnal.ugm.ac.id/rpcpe

(Kajian Praktik dan Pendidikan Layanan Primer)

\title{
Understanding Cough Ethics and Changes of Behavior of Kindergarten Teachers in the Work Area of Puskesmas Sedayu I: Community-Based Health Efforts
}

\author{
Sistia Utami ${ }^{1}$, Mora Claramita ${ }^{2}$, Wahyudi Istiono ${ }^{3}$ \\ ${ }^{1}$ Primary Health Care Center/Pusat Kesehatan Masyarakat (Puskesmas) Sedayu I; Indonesia \\ 2 Department of Medical Education and Bioethics; Faculty of Medicine, Public Health and Nursing; Universitas Gadjah Mada; Indonesia \\ ${ }^{3}$ Department of Family and Community Medicine; Faculty of Medicine, Public Health and Nursing; Universitas Gadjah Mada; Indonesia
}

Corresponding Author:

Sistia Utami: Primary Health Care Center/Pusat Kesehatan Masyarakat (Puskesmas) Sedayu I, Panggang, Argomulyo, Sedayu Bantul, Daerah Istimewa Yogyakarta - 55752, Indonesia

E-mail: sistia.utami72@gmail.com

To cite this article:

Utami S, Claramita M, Istiono W. Understanding cough ethics and changes of behavior of kindergarten teachers in the work area of Puskesmas Sedayu I: community-based health efforts. Rev Prim Care and Educ. 2020; 3(1): 15-23.

\begin{abstract}
Background: Cough cases are increasing every year. The most common cause is a virus. Coughing is influenced by endurance, Cough Ethics, and Handwashing with Soap/Cuci Tangan Pakai Sabun (CTPS). Transmission occurs through droplets in the air from the patient when coughing or sneezing. We need to educate the community to minimize transmission, especially among children. Ultimately, this speeds up the healing process. Objective: This study aimed to provide an understanding of Cough Ethics and behavior change using narrative in action to kindergarten teachers. Method: This study used descriptive-analytic qualitative methods with narrative in action. The subjects of the study were a population of kindergarten teachers in the working area of the Puskesmas Sedayu 1, selected purposive snowball sampling. Retrieval of data was done through the observation stage, pre-narrative in action activities, the narrative in action, post narrative in action activities, and the final observation stage in kindergarten. Result: Observations were done at the school to find out the infrastructure. Observation before and after the demonstration showed there were improvements and concluded that all can demonstrate the Cough Ethics and CTPS. Watching the Cough Ethics video, CTPS, followed by the dialogue, motivation, education, persuasion, promotion were empowering for the teachers to change their behavior. All groups when coughing or sneezing covered their nose and mouth with a tissue, mask, or the inner side of elbow arm or expelled phlegm on the ground, lodong/special place like a jar, and toilet. Conclusion: Narrative in action activities are an alternative way of providing understanding to change behavior. Watching videos makes it easy to explain the Ethics of Cough. Practice is needed to improve the skills of narrative in action.
\end{abstract}

Keywords: cough ethic, CTPS, narrative in action

\section{INTRODUCTION}

One of the Puskesmas activities according to the Ministry of Health Regulation No. 75 of 2014, is Community-Based Health Efforts/Upaya Kesehatan Berbasis Masyarakat (UKBM), which is more focused on promoting and preventive efforts by involving all levels of society, including kindergarten teachers ${ }^{1}$. One of the preventive promotive efforts in UKBM is the prevention and control of infectious diseases. Transmission of infectious diseases such as the common cold in schoolchildren is very easy. The common cold disease does not happen seasonally and can be experienced by anyone throughout the year. Common cold, influenza, and pharyngitis can be experienced by anyone whose immune system is decreasing ${ }^{2}$. This disease can easily attack people with low endurance and in some circumstances only by resting and eating a balanced diet, can sufferers improve ${ }^{3}$. The number of common cold sufferers in pre-school age children in Puskesmas Sedayu I tended to increase from 2013, 2014, and 2015, specifically 674,628 , and 715 cases. Common cold and acute pharyngitis have always been counted in the 10 most diseases over the past 3 years for all ages ${ }^{4,5,6}$.

Coughing is a symptom of a disease caused either by infection or non-infection. Infectious disease is one caused by germs in the form of bacteria, viruses, fungi, parasites, and not caused by physical factors (burns) or chemicals (poisoning). Mode of transmission of disease can occur through direct media on the surface of the skin of people to people or air media directly in the form of droplets or saliva splashes or indirectly through water borne? ${ }^{7}$. Direct transmission usually occurs through sneezing or coughing. Coughing also occurs in people with GERD, chronic lung conditions such as asthma, COPD, pulmonary fibrosis, and lung tissue disease, and can also be due to embolism, or heart failure congestion ${ }^{8}$. Infectious Disease Control and Prevention Program/Program Pengendalian dan Pencegahan Penyakit Infeksi (PPI) has been routinely 
conducted by Puskesmas. Communities and staff have an increased risk of contracting diseases through daily contact with sick patients. For health officers, early warning standards are applied using masks and CTPS ${ }^{9}$.

The most common behavior is not wearing personal protective equipment such as masks and CTPS. Compliance in washing hands with soap and water together is recommended because it reduces the incidence of illness that comes from the environment compared to washing hands with an alcohol-based liquid ${ }^{10}$. Fulfillment of proper infrastructure is also needed to minimize cough transmission, especially in the school environment. The application of standard precautions in health care facilities starts with health workers serving in health services, applied in daily activities, especially when on duty ${ }^{11}$. When there are no tissues, you can use your inner side of elbow arm when coughing or sneezing, and if there is fluid coming out through the nose, use tissue or discharge sputum into the toilet or in a special place filled with antiseptic fluid ${ }^{12,13}$. This study aimed to provide an understanding of Cough Ethics and behavior change using narrative in action by kindergarten teachers so that teachers can be an example and healthy role model of Cough Ethics for kindergarten children.

\section{RESEARCH METHODS}

This research was descriptive-analytic study with a qualitative approach. This research used narrative in action with 6 steps of activities consisting of dialogue, motivation, education, persuasion, promotion, and empowerment. Each step consists of questions: (1) What do you do when you cough or sneeze?; (2) If you don't wear a mask or tissue, what do you do ?; (3) If your hands get wet with coughing or sneezing splashes, what do you do ?; and (4) If you cough and there is phlegm, where do you get rid of the phlegm?

Descriptive research is conducted to describe, interpret, and explain social situations. Descriptions are in the form of phenomena found, risk factors, and effects or results. Subjects were divided into 3 groups due to the busy schedule of the teachers so that the grouping was based on the similarity of time the subjects had when they were going to be observed.

The population were kindergarten teachers in the working area of the Puskesmas Sedayu 1. The sampling technique was purposive snowball sampling in 15 kindergartens and 36 teachers. Inclusion criteria were: (1) Kindergarten teachers who work in the work area of Puskesmas Sedayu 1; (2) Willing to be a respondent; (3) Not yet retired in the next 5 years; and (4) Not being treated by a doctor. Exclusion criteria: (1) Kindergarten teachers who do not live in the District of Sedayu; and (2) Not a kindergarten teacher.

Table 1. Research variable

\begin{tabular}{ll}
\hline Subject & Variable \\
\hline Group & 1. Closing the nose-mouth using a mask or tissue when sneezing and coughing \\
& 2. Using the inner side of elbow arm/sleeve while sneezing and coughing \\
& 3. Wash hands with soap in running water \\
& 4. Throw sputum in toilet/container that has been given antiseptic \\
\hline
\end{tabular}

The method of data analysis used audio-visual recordings from the observation, interview and demonstration stages as pre-narrative in action activities, including the narrative in action recorded sounds, post narrative in action recorded audiovisuals, and finally finished with analyzing pre and post engagements by simple coding.

\section{RESULTS AND DISCUSSION}

Screening several videos about cough ethics is a way to attract attention early in the activity. The results of the narrative in action can be seen in appendix 1. The dialogue activities of the respondents could be directed more by referring to the video watched, and reactions from the three dialogue groups developed according to the participants' understanding. Almost all participants actively said they were in the habit of closing their noses when coughing or sneezing and using a handkerchief, tissue, mask, or inner elbow. The question of why use a mask was appropriately answered by fellow respondents. The question about the effectiveness of using the inner side of elbow arm in group 3 was raised by one of the respondents. Dialogue about correct CTPS was also inserted into the health promotion.

Motivating activities according to Sulaksana tend to be done in 2 directions $^{14}$, so also in this activity motivating respondents to use tissues, masks, and the inner side of elbow arm when coughing or sneezing in each group. The goal was motivating to want to wear the right mask, how to get rid of tissues, masks, the right reaction, and how to CTPS sequentially. In group 3 respondents were found motivated to the use of the inner elbow when coughing or sneezing.

Educational and promotional activities tended to be one-way from the Researchers and also in answering respondents' questions. Some respondents in each group were enthusiastic about asking why it is safer to wear a disposable mask, about the causes of coughing, and why use the inner side of elbow arm.

The persuasion step was done with respondents who still use a handkerchief urging them to pay attention to how to treat a handkerchief after use. Also, respondents who still use their hands to cover their nose and mouth when coughing or sneezing were urged to do the correct CTPS as soon as possible. It was explained that the effect of not closing the nose-mouth when coughing will spread airborne diseases such as common cold ${ }^{15}$. But the activities did not appear to show there was a good promotional effort. 
Table 2. Guidelines of the narrative in action

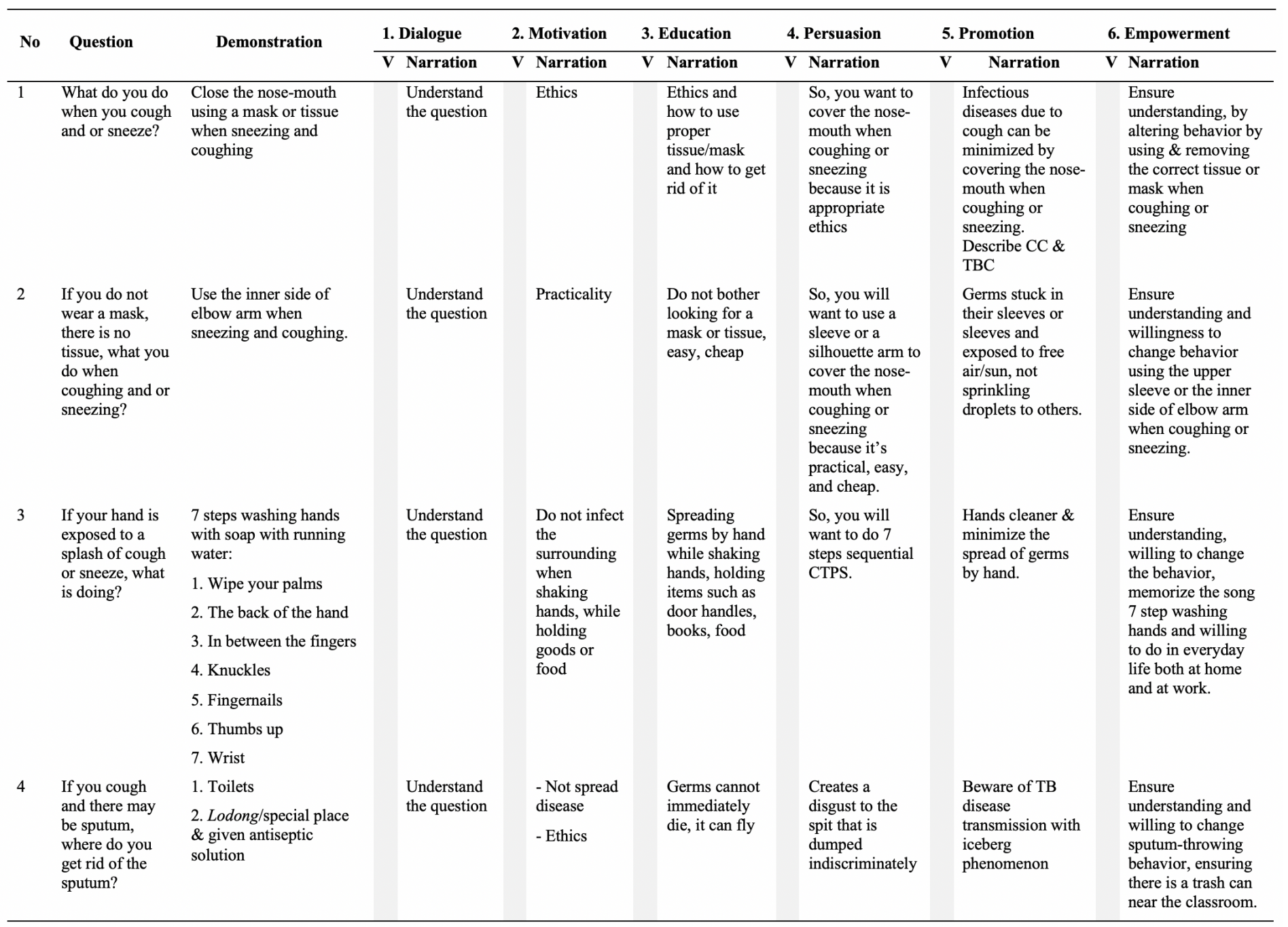

Table 3. Preliminary and final observation results

\begin{tabular}{|c|c|c|c|c|c|c|c|c|c|c|c|c|c|c|c|c|c|}
\hline \multirow{3}{*}{ No } & \multirow{3}{*}{ School } & \multicolumn{16}{|c|}{ Observation } \\
\hline & & \multicolumn{2}{|c|}{$\begin{array}{l}\text { Children } \\
\text { know the } \\
\text { song of } \\
\text { CTPS }\end{array}$} & \multicolumn{2}{|c|}{$\begin{array}{c}\text { Available } \\
\text { masks }\end{array}$} & \multicolumn{2}{|c|}{$\begin{array}{l}\text { Poster } \\
\text { PHBS }\end{array}$} & \multicolumn{2}{|c|}{$\begin{array}{l}\text { Faucet } \\
\text { water in } \\
\text { the yard }\end{array}$} & \multicolumn{2}{|c|}{$\begin{array}{c}\text { Soap/ } \\
\text { hand rub }\end{array}$} & \multicolumn{2}{|c|}{$\begin{array}{c}\text { Tissue/ } \\
\text { clean } \\
\text { napkins }\end{array}$} & \multicolumn{2}{|c|}{$\begin{array}{c}\text { Closed } \\
\text { bins }\end{array}$} & \multicolumn{2}{|c|}{ Toilet } \\
\hline & & $\mathrm{A}$ & $\mathrm{B}$ & $\mathrm{A}$ & $\mathrm{B}$ & $\mathrm{A}$ & $\mathrm{B}$ & $\mathrm{A}$ & $\mathrm{B}$ & $\mathrm{A}$ & $\mathrm{B}$ & $\mathrm{A}$ & B & $\mathrm{A}$ & $\mathrm{B}$ & $\mathrm{A}$ & $\mathrm{B}$ \\
\hline 1 & TK PKK 30 AM & - & $\mathrm{V}$ & - & - & $\mathrm{V}$ & $\mathrm{V}$ & $\mathrm{V}$ & $\mathrm{V}$ & - & $\mathrm{V}$ & - & $\mathrm{V}$ & $\mathrm{V}$ & $\mathrm{V}$ & $\mathrm{V}$ & $\mathrm{V}$ \\
\hline 2 & TK PKK 29 AM & - & $\mathrm{V}$ & - & - & - & - & V & $\mathrm{V}$ & $\mathrm{V}$ & $\mathrm{V}$ & - & V & - & V & V & V \\
\hline 3 & TK Pertiwi $61 \mathrm{Kl}$ & - & $\mathrm{V}$ & - & - & - & V & V & $\mathrm{V}$ & - & V & - & V & - & - & $\mathrm{V}$ & V \\
\hline 4 & TK ABA TAPEN & - & $\mathrm{V}$ & $\mathrm{V}$ & $\mathrm{V}$ & - & - & $\mathrm{V}$ & $\mathrm{V}$ & $\mathrm{V}$ & $\mathrm{V}$ & - & V & $\mathrm{V}$ & $\mathrm{V}$ & $\mathrm{V}$ & V \\
\hline 5 & TK ABA SEDAYU & - & $\mathrm{V}$ & - & - & - & - & $\mathrm{V}$ & V & - & V & - & V & $\mathrm{V}$ & V & V & V \\
\hline 6 & TK ABA AM & - & $\mathrm{V}$ & - & - & - & - & V & $\mathrm{V}$ & - & $\mathrm{V}$ & $\mathrm{V}$ & V & - & V & $\mathrm{V}$ & V \\
\hline 7 & TK PKK 7 AM & - & $\mathrm{V}$ & - & - & - & - & $\mathrm{V}$ & $\mathrm{V}$ & - & $\mathrm{V}$ & - & $\mathrm{V}$ & - & $\mathrm{V}$ & $\mathrm{V}$ & $\mathrm{V}$ \\
\hline 8 & TK ABA PEDUSAN & - & $\mathrm{V}$ & - & - & $\mathrm{V}$ & $\mathrm{V}$ & $\mathrm{V}$ & $\mathrm{V}$ & - & $\mathrm{V}$ & - & $\mathrm{V}$ & - & V & $\mathrm{V}$ & V \\
\hline 9 & TK PKK 28 AM & - & V & - & - & V & $\mathrm{V}$ & V & V & - & V & - & V & - & - & V & V \\
\hline 10 & TK PKK 4 AM & - & $\mathrm{V}$ & $\mathrm{V}$ & $\mathrm{V}$ & - & $\mathrm{V}$ & - & - & - & - & $\mathrm{v}$ & - & $\mathrm{V}$ & $\mathrm{V}$ & $\mathrm{V}$ & V \\
\hline 11 & $\begin{array}{l}\text { TK PKK MAWAR } \\
\text { PUTIH }\end{array}$ & - & - & - & - & $\mathrm{V}$ & $\mathrm{V}$ & $\mathrm{V}$ & $\mathrm{V}$ & $\mathrm{V}$ & $\mathrm{V}$ & - & $\mathrm{V}$ & - & - & $\mathrm{V}$ & $\mathrm{V}$ \\
\hline 12 & $\begin{array}{l}\text { TK PKK } 35 \text { MEKAR } \\
\text { RINI }\end{array}$ & - & $\mathrm{V}$ & - & - & $\mathrm{V}$ & $\mathrm{V}$ & $\mathrm{V}$ & $\mathrm{V}$ & - & $\mathrm{V}$ & - & V & - & $\mathrm{V}$ & $\mathrm{V}$ & $\mathrm{V}$ \\
\hline 13 & TK PKK $10 \mathrm{AM}$ & - & $\mathrm{V}$ & - & - & - & V & $\mathrm{V}$ & $\mathrm{V}$ & - & $\mathrm{V}$ & - & $\mathrm{V}$ & - & V & & \\
\hline 14 & TK ST THERESIA & - & V & - & - & - & V & V & V & - & $\mathrm{V}$ & - & $\mathrm{V}$ & $\mathrm{V}$ & V & $\mathrm{V}$ & $\mathrm{V}$ \\
\hline 15 & TKIT BINA INSAN & - & $\mathrm{V}$ & - & - & - & $\mathrm{V}$ & $\mathrm{V}$ & $\mathrm{V}$ & - & $\mathrm{V}$ & - & $\mathrm{V}$ & - & - & V & V \\
\hline
\end{tabular}

$\mathrm{V}$ : available/know/able

-: available/not know/not able

A: start

B: end 
However, at the end of the activity, there were empowerment efforts by concluding together, agreeing, asking for willingness to become a role model, and conveying the correct Cough Ethics.

The results of the initial and final observations after the narrative in action can be seen in Table 3 below. Pre and post narrative in action activities were used to assess understanding and behavior changes after exposure to the narrative in action.

The initial stage was done by observing, visiting a kindergarten, seeing and talking with kindergarten students as well as teachers. The results of initial observations found $100 \%$ of students and teachers do not know the correct steps of CTPS.

Final observation after 3 months of the last narrative in action activity, namely in April week III, showed there was significant change in all teachers and students who now already know the 7-step hand washing song with 93.33\% of kindergarten. The PHBS (Clean and Healthy Life Behavior) poster increased by $100 \%$ from 5 schools to 10 schools. Kindergarten schools that are being renovated are using water taps for ablution in the mosque next to the location.

Solid or liquid soap already exists near the water tap, and there were an additional 12 locations up from $20 \%$ to $100 \%$. Tissues or napkins were already available around the place to wash hands. Most sites had closed trash bins and several begin to have dry and wet waste sorting with a change from $33.33 \%$ to $73.33 \%$ having closed trash. All kindergarten schools already have well-maintained bathrooms. Some children who are coughing still use their arms to cover their nose and mouth.

\section{CONCLUSIONS}

The activity that begins with watching the video makes it easier to implement steps in the narrative in action. Cough Ethics can also be socialized with narrative in action. When coughing or sneezing, closing your mouth to the bottom of the nose with the forearm to the elbow is more practical than using a tissue or mask. Steps to wash hands with soap are easy to remember by singing. Removing phlegm or nasal discharge is better in the bathroom. In patients with the chronic or old disease tissues can be disposed temporarily in a lodong. In the room, there should be a closed trash bin. The results of the final observation after 3 months of narrative in action, found a significant change in doing the Cough Ethics properly.

\section{Acknowledgment}

The authors are grateful to all those who helped complete the research.

\section{Ethical Approval and Informed Consent}

This research has been approved by the Medical and Health Research Ethics Committee (MHREC) from the Faculty of Medicine, Public Health and Nursing, Universitas Gadjah Mada.

\section{Funding}

Self-funding.

\section{Availability of Data and Material}

Data and material can be accessed via the corresponding author.

\section{Conflict of Interest}

None.

\section{REFERENCES}

1. Ministry of Health Republic of Indonesia. Ministry of health regulation no. 75 of 2014 on primary care health center. Republic of Indonesia Public Letter of 2014 No. 1676. Jakarta: Ministry of Health Republic of Indonesia; 2014.

2. Aiello AE, Murray GF, Perez V, Coulborn RM, Davis BM, Uddin M, Shay DK, Waterman SH, Monto AS. Mask use, hand hygiene, and seasonal influenza-like illness among young adults: a randomized intervention trial. The Journal of Infectious Diseases. 2010; 201(4): 491-8.

3. World Health Organization. Cough and cold remedies for the treatment of acute respiratory infections in young children. Geneva: World Health Organization; 2001. Available from: https://apps.who. int/iris/bitstream/handle/10665/66856/WHO_FCH_CAH_01.02. pdf? sequence $=1$

4. Puskesmas Sedayu I. Puskesmas Sedayu I profile. Bantul: Puskesmas Sedayu I; 2013.

5. Puskesmas Sedayu I. Puskesmas Sedayu I profile. Bantul: Puskesmas Sedayu I; 2014.

6. Puskesmas Sedayu I. Puskesmas Sedayu I profile. Bantul: Puskesmas Sedayu I; 2015.

7. Three ways of transmitting infectious diseases [homepage on the Internet]. c2012. Available from: http://www.smallcrab.com/ kesehatan/1186-tiga-cara-penularan-penyakit-infeksi.html.

8. Turner RD, Bothamley GH. Chronic cough and a normal chest x-ray - a simple systematic approach to exclude common causes before referral to secondary care: a retrospective cohort study. NPJ Primary Care Respiratory Medicine. 2016; 26: 15081.

9. Directorate General of Medical Services. Managerial guidelines for infection protection in hospitals and other health care facilities. Jakarta: Ministry of Health Republic of Indonesia; 2008.

10. Savolainen-Kopra C, Haapakoski J, Peltola PA, Ziegler T, Korpela T, Anttila P, Amiryousefi A, Huovinen P, Huvinen M, Noronen H, Riikkala P, Roivainen M, Ruutu P, Teirilä J, Vartiainen E, Hovi T. Hand washing with soap and water together with behavioural recommendations prevents infections in common work environment: an open cluster-randomized trial. Trials. 2012; 13: 10.

11. World Health Organization. Hand hygiene technical reference manual. Geneva: World Health Organization; 2009. Available from: https:// apps.who.int/iris/bitstream/handle/10665/44196/9789241598606_ eng.pdf? sequence $=1$

12. Berry TD, Fournier AK. Examining university students' sneezing and coughing etiquette. American Journal of Infection Control. 2014; 42(12): 1317-8.

13. World Health Organization. Implementation of standard precautions in health care facilities: infection prevention and control. 2008. Available from: https:/www.who.int/csr/resources/publications/ AMStandardPrecautions_bahasa.pdf?ua=1.

14. Sulaksana U. Change Management. Yogyakarta: Pustaka Pelajar; 2004.

15. Samanta GP. Analysis of a nonautonomous dynamical model of diseases through droplet infection and direct contact. Applied Mathematics and Computation. 2011; 217(12): 5870-88. 
APPENDIX 1

Table of the Narrative in Action at Group

\begin{tabular}{clll}
\hline \multirow{2}{*}{ No } & $\begin{array}{l}\text { Narrative in } \\
\text { Action }\end{array}$ & Question & \multicolumn{1}{c}{ Group I } \\
\cline { 3 - 4 } & Dialog & What do you & 1) Yesponse Participants \\
do when you & after using tissue, it must be \\
cough or & discarded/thrown. That's \\
sneeze? & $\begin{array}{l}\text { right ma'am, use tissue after } \\
\text { coughing? Is it right, }\end{array}$ \\
& & ma'am? \\
& & (2) How about wearing a \\
& & handkerchief, if there are no \\
& & tissues? \\
& & (3) After coughing, after \\
& & coughing, yes it (tissue) is \\
& & thrown in the trash, then we \\
& & immediately wash hands.
\end{tabular}

(4) Tissues

If you do not wear a mask or use tissue, what do you do?

If your hands are splashed by coughing or sneezing, what are you doing?
If you cough and there may be sputum, where do you get rid of the sputum?
(1) The easiest way is to use the inner side of elbow arm like the example in the video, it is not difficult to find a tissue or handkerchief, unless there is a crack means to throw it away the tissue or in the bathroom (Researcher). (2) Use a mask, right? (1) Using hands is actually in my opinion if it's okay, then after that immediately look for water, and then wash your hands using 7 steps to wash hands with soap like the film earlier. (2) But if you use spray it also contains alcohol, can you buy it to wash your hands?

(3) Well that's it, so we spray 4 times the taste is also not enough for cleaning.

(4) Yeah, and sometimes it's still dry, but before we used it (pointing to the one provided) why is it like that?

(1) Suppose there is no trash, then I look elsewhere there is no trash, then I pocket it, is the influence not germs? (2) If you don't bring plastic?

(3) The important thing is the bag can be hit by free air later.

(4) As a child, there are grandmothers who use it to chew special leaves (to dispose of the results of the used-chewing special

Group II

Response Participants

(1) If I am in front of the children, I still immediately run to the bathroom. If you do not use tissue, I will cover it when I cough.

(2) Take a tissue, after coughing just take (demonstrate cough with tissue). But if I was teaching, I immediately ran out to the bathroom.

(3) When coughing or sneezing, what you do is drink salt water. If not, then drink salt water mixed with soy sauce and oranges to treat it.

(4) First, we must cover our mouths with tissue, then we throw the tissue in a closed trash can

(5) Cover with a tissue (practice coughing with a tissue)

(6) Not facing other people, keep having to be ready with tissue at least covered so as not to spread to others.

(1) Then open the mask and try to cough covered in the arm (participant).

(1) Doctor, can we try the 7 steps to wash hands? I just heard.

(2) Training time has been shown.

(3) While to the former rice warehouse, fortunately there is a mosque next door. So, the children wash their hands in the ablution place. Do you have a cleaning liquid, expensive, ma'am? (4) If the teacher does not use the liquid, if the children are wasteful.

(5) How to use cleaning fluid with the 7 steps to wash hands with soap?

(6) It's better to use soap and running water.

(7) Is it different or not? Is the sneezing of someone with the right sneezing with someone with the flu different or not?

(1) On the ground, continue to be covered using soil.

(2) In the bathroom ma'am.

(3) On the lawn alone, the sun is exposed to direct germs.

(4) You may throw it in the tissue.

(5) Dispose of directly in the trash?

(6) Poor people who clean trash cans, yes if they are in a plastic cage first. In Srontakan Kindergarten who coughs, the teacher goes to the bathroom.

(7) If the cough is very frequent and the phlegm/sputum is many,
Group III Response Participants

(1) Wash hands after covering mouth with both hands.

(2) Use the arm when coughing

(3) Wear a mask when in class when coughing and flu.

(1) Yes doctor, it's more easily to use arms, then tissue, mask, tomorrow dumped into the trash, simple but often forgot.

(1) Some respondents answered, "Wash hands with soap". Others add "Rinse with flowing water".

Usually I cough there is a reaction. When I taught, my reaction was swallowed. But if the cough continues, I go out first, cough in the bathroom or drink water. If in the bathroom, my reaction will be thrown in the toilet.

(1) Some tell a few years before his mother died of coughing, he prepared a used biscuit can whose contents were given antiseptic solution. Every morning and evening he turns with his brother to throw it in the front sewer. 


\begin{tabular}{|c|c|c|c|c|c|}
\hline \multirow{2}{*}{ No } & \multirow{2}{*}{$\begin{array}{l}\text { Narrative in } \\
\text { Action }\end{array}$} & \multirow{2}{*}{ Question } & Group I & Group II & Group III \\
\hline & & & Response Participants & Response Participants & Response Participants \\
\hline 2 & Motivation & $\begin{array}{l}\text { What do you } \\
\text { do when you } \\
\text { cough or } \\
\text { sneeze? }\end{array}$ & $\begin{array}{l}\text { Mouth and nose. So not } \\
\text { only the mouth, but also the } \\
\text { nose. So, this must cover all. } \\
\text { So, if you take a sheet and it } \\
\text { is not enough, you can take } \\
2 \text { sheets. Don't use toilet } \\
\text { paper. Yes, that's OK, but } \\
\text { it's really coughing. So } \\
\text { that's how it is mom, take } \\
\text { enough, keep it closed, not } \\
\text { only the mouth but also the } \\
\text { nose. Oh, Mr. Nur said } \\
\text { earlier "Yes if there is } \\
\text { tissue". Well, please try Mr. } \\
\text { Nur, practice it. So how to } \\
\text { wear the right mask? } \\
\text { (Researcher). Yes, we see } \\
\text { the fold. If it's the right one, } \\
\text { the outer one folds out of } \\
\text { the bag. So, for example I } \\
\text { drag here it falls. But if we } \\
\text { go back, try behind that } \\
\text { inside if we put something }\end{array}$ & $\begin{array}{l}\text { is there a way that can help, } \\
\text { especially if the cough is } \\
\text { grandfather/grandmother? } \\
\text { (8) My neighbor's grandmother } \\
\text { when I was little near her bed } \\
\text { had a biscuit can to dispose of, } \\
\text { salted sand, every day the sand } \\
\text { was replaced and what was } \\
\text { salivated or broken in the } \\
\text { backyard, if now is that still the } \\
\text { case? } \\
\text { (9) Maybe today still works, but } \\
\text { not all houses have sand, can } \\
\text { they be covered with plastic? } \\
\text { (1) We take tissue, we cover it, } \\
\text { then we throw it in the trash, } \\
\text { (demonstrating a cough with } \\
\text { tissue). When we fit in front of } \\
\text { the children, we turn our heads. } \\
\text { If we walk, we cannot, at most it } \\
\text { only leads to the other side. } \\
\text { Researcher agrees. "Even if we } \\
\text { sneeze just once the germs or } \\
\text { viruses that we spend are } \\
\text { millions. So, it's no longer one, } \\
\text { two, three, ma'am, but millions } \\
\text { of germs or virus". }\end{array}$ & $\begin{array}{l}\text { (1) I used to buy colorful, } \\
\text { washable, no wires, just a little } \\
\text { nose and mouth cover, no folds. } \\
\text { It's comfortable to wear because } \\
\text { it's exposed to the wind or cool } \\
\text { (participants). Researcher's } \\
\text { response "How many days do you } \\
\text { wash it, Mother? If you are not } \\
\text { sick it is not a problem mom, but } \\
\text { if you cough because of an allergy } \\
\text { or a cold cough due to an } \\
\text { infection?". } \\
\text { (2) Wash 3-4 days. It should be } \\
\text { every day, yes (Researcher). } \\
\text { (3) There were other respondents } \\
\text { who were shocked and ashamed, } \\
\text { "I sometimes washed it for } 5 \text { days, } \\
\text { mom." Researcher "Wow, you } \\
\text { keep germs in a mask". So, it is } \\
\text { better if you are coughing with } \\
\text { disposable masks or diligently } \\
\text { washing mask material. }\end{array}$ \\
\hline
\end{tabular}

If you do not wear a mask or use tissue, what do you do?

If your hands are splashed by coughing or sneezing, what are you doing?
Actually, in my opinion, it's okay to use your hands, then immediately look for water, then wash your hands the 7 steps of CTPS like the film (participant). Another respondent suddenly said "Please practice it" (Researcher).
Others try to cough when wearing a mask and say, "It's hard to breathe, it's better to use your arms". Then open the mask and try to cough covered with arms. "More relieved".

Researcher "Yes, so that's how it is. So how can you use it? So, if you cough? The answer is wearing a mask earlier and it's more practical to use your inner side of elbow arm. Anything else you want to add?"

Please try it, isn't it suitable for the 7 steps of CTPS?

(Researcher). All participants tried the 7 steps of CTPS. Anyone wants to compare with soap. He invited us to a hand washing area near the hall and argued "It's better to use soap and running water". The opinion of other respondent colleagues "Yes sometimes if you just urge to use fluids".
Get used to wash hands with soap and running water (Researcher). Some respondents have memorized it. 


\begin{tabular}{|c|c|c|c|c|c|}
\hline \multirow{2}{*}{ No } & \multirow{2}{*}{$\begin{array}{l}\text { Narrative in } \\
\text { Action }\end{array}$} & \multirow{2}{*}{ Question } & Group I & Group II & Group III \\
\hline & & & Response Participants & Response Participants & Response Participants \\
\hline \multirow{3}{*}{4} & \multirow{3}{*}{ Persuasion } & $\begin{array}{l}\text { If you cough } \\
\text { and there } \\
\text { may be } \\
\text { sputum, } \\
\text { where do } \\
\text { you get rid } \\
\text { of the } \\
\text { sputum? }\end{array}$ & $\begin{array}{l}\text { Now this is a trash can. } \\
\text { Sorry, what's next to it ... } \\
\text { lodong (like a jar), able to } \\
\text { remove phlegm. Isn't that } \\
\text { like there are small places? } \\
\text { Well, the most important } \\
\text { thing is the jar (Researcher). }\end{array}$ & $\begin{array}{l}\text { (1) Ladies, if you cough with } \\
\text { phlegm, change your reaction in } \\
\text { the toilet or tissue, then throw it } \\
\text { in a trash bin exposed to the sun } \\
\text { or if in the trash bin, what } \\
\text { should you think, ladies and } \\
\text { gentlemen? (Researcher). } \\
\text { (2) Yes ma'am, you can, but } \\
\text { still, from plastic waste to the } \\
\text { toilet, ma'am, unless you have } \\
\text { large sand or land that is } \\
\text { exposed to the sun, you can use } \\
\text { it (Researcher). }\end{array}$ & \\
\hline & & $\begin{array}{l}\text { What do you } \\
\text { do when you } \\
\text { cough or } \\
\text { sneeze? }\end{array}$ & & $\begin{array}{l}\text { Yes, so that's how it is. So how } \\
\text { can you use it? So, if you } \\
\text { cough? The answer is wearing a } \\
\text { mask earlier and it's more } \\
\text { practical to use your inner side } \\
\text { of elbow arm. Anything else } \\
\text { you want to add? (Researcher). }\end{array}$ & $\begin{array}{l}\text { (1) Getting used to wash the hands } \\
\text { with soap and flowing water (from } \\
\text { the participant). } \\
\text { (2) If being taught may be } \\
\text { difficult, later the children will not } \\
\text { be clear with the teacher's voice, } \\
\text { detained first and then leave the } \\
\text { class to cough, especially if you } \\
\text { cough continuously. } \\
\text { (3) I used to buy colorful, } \\
\text { washable, no wires, just a little } \\
\text { nose and mouth cover, no folds. } \\
\text { It's comfortable to wear because } \\
\text { it's exposed to the wind or cool }\end{array}$ \\
\hline & & $\begin{array}{l}\text { If your } \\
\text { hands are }\end{array}$ & $\begin{array}{l}\text { Like this? (showing the } \\
\text { handrub) }\end{array}$ & $\begin{array}{l}\text { (1) Alhamdulillah, everyone is } \\
\text { happy, tomorrow please teach }\end{array}$ & $\begin{array}{l}\text { Remember the } 7 \text { steps to wash } \\
\text { hands (Researcher) }\end{array}$ \\
\hline
\end{tabular}

splashed by

coughing or

sneezing,

what are you

doing?

If you cough Yes, it is better put plastic to and there be easily disposed of in a may be sun-draped garbage can or sputum, throw into a closet. It is where do usually necessary to prevent you get rid blockage for difficult of the sewage in the bathroom. sputum? Especially if you have an cough or sneeze? folds out of the bag. So, for still won't fall. Take a look
If your

hands are splashed by coughing or sneezing, what are you doing? If you cough and there may be sputum, where do you get rid of the sputum? infection like tuberculosis (Researcher).

es, we see the fold. If it's he right one, the outer one example I drag here it falls. But if we go back, try behind that inside if we put something in here then it at this (demonstrate by putting a pen in the fold)

hands (Researcher).

(2) Yes, it may be thrown in the toilet maybe yes, it's uncomfortable to hear that people want to dump the mucus.

The conclusion is more understanding, right ma' am. After trying the mask when coughing, cover your nose to mouth with a tissue, and compare it with your arms (Researcher).

(1) We get it from the public health office (point to the hand rub) (Researcher)

(2) Right ma'am, it is safer and guaranteed cleaner by handwashing with soap with flowing water (Researcher) Yes ma'am, it can, but still, throw plastic waste to the toilet, he Rearcher affirm and added "It would be safer if the sputum is thrown ma'am, unless you have large

into the closet and watered sand or land that is exposed to thoroughly".

Conclude about the correct Cough Ethics, using a mask when coughing, runny nose, closing the nose-mouth using tissue or the inner side of elbow arm when sneezing or coughing, CTPS, and the sun, you can use it (Researcher)

At the end of the narrative in action activity, the respondents were able to receive a concise understanding and explanation of the Cough Ethics and CTPS. The respondents are willing to teach the 7 steps of CTPS and
Researcher said that it is safer to dispose of the closet or make a hole to throw sputum than on the ground to prevent germs from spreading.

(1) Do you wash it every other day? If you are not sick, then no problem, but if you cough due to an allergy or a cold cough due to an infection?

(2) There are still germs that can infect other people.

There are 7 steps to wash the hands from front to back, between fingers, knuckles, fingernails, wrist thumbs (Researcher sing)

Activities closed by practicing Cough Ethics, washing hands with soap, and a commitment to teach Cough Ethics to kindergarten students. 


\begin{tabular}{|c|c|c|c|c|c|}
\hline \multirow{2}{*}{ No } & \multirow{2}{*}{$\begin{array}{l}\text { Narrative in } \\
\text { Action }\end{array}$} & \multirow{2}{*}{ Question } & Group I & Group II & Group III \\
\hline & & & Response Participants & Response Participants & Response Participants \\
\hline & & & $\begin{array}{l}\text { how to properly expel } \\
\text { phlegm in the toilet. }\end{array}$ & $\begin{array}{l}\text { inform about Cough Ethics in } \\
\text { the school and family. }\end{array}$ & \\
\hline & & $\begin{array}{l}\text { If you do not } \\
\text { wear a mask } \\
\text { or use tissue, } \\
\text { what do you } \\
\text { do? }\end{array}$ & $\begin{array}{l}\text { Conclude to close the nose- } \\
\text { mouth using the inner side } \\
\text { of elbow arm. }\end{array}$ & $\begin{array}{l}\text { Receive understanding using the } \\
\text { inner arm elbow. }\end{array}$ & $\begin{array}{l}\text { Being able to practice covering } \\
\text { the nose-mouth with the inner side } \\
\text { of elbow arm. }\end{array}$ \\
\hline & & $\begin{array}{l}\text { If your } \\
\text { hands are } \\
\text { splashed by } \\
\text { coughing or } \\
\text { sneezing, } \\
\text { what are you } \\
\text { doing? }\end{array}$ & $\begin{array}{l}\text { Concludes about proper } \\
\text { hand washing with the } 7 \\
\text { steps of CTPS. }\end{array}$ & $\begin{array}{l}\text { Th respondents are willing to } \\
\text { teach the } 7 \text { steps of CTPS. }\end{array}$ & $\begin{array}{l}\text { Wash hands after closing the } \\
\text { mouth with both hands. }\end{array}$ \\
\hline & & $\begin{array}{l}\text { If you cough } \\
\text { and there } \\
\text { may be } \\
\text { sputum, } \\
\text { where do } \\
\text { you get rid } \\
\text { of the } \\
\text { sputum? }\end{array}$ & $\begin{array}{l}\text { Conclude about how to } \\
\text { properly expel phlegm in } \\
\text { the closest garbage. }\end{array}$ & $\begin{array}{l}\text { The respondents are willing to } \\
\text { inform Cough Ethics (one of } \\
\text { them is a place to dispose of } \\
\text { sputum) in the school and } \\
\text { family. }\end{array}$ & $\begin{array}{l}\text { Commitment to teach Cough } \\
\text { Ethics to kindergarten students. }\end{array}$ \\
\hline
\end{tabular}


Sistia Utami et al. | Understanding Cough Ethics and Changes of Behavior of... | Research Article 23 